Justyna KUŚWIK

Uniwersytet Szczeciński

\title{
Konflikt polityczny z perspektywy teorii zachowania zasobów
}

7 jawisko konfliktu jest powszechnym i naturalnym elementem życia społecznego człowieka. Pojawia się na różnych jego poziomach (indywidualnym, grupowym), może wystąpić w różnych sferach. Trudno znaleźć taki obszar życia, w którym konflikt nie może się pojawić. Niniejszy artykuł w szczególny sposób dotyczy i obejmuje swoją tematyką konflikt polityczny.

Pojęcie konfliktu może być rozumiane w trojaki sposób, po pierwsze jako tkwiąca w strukturze systemu niezgodność, wzajemne wykluczanie się celów grupowych, spowodowane ograniczoną ilością powszechnie pożądanych dóbr. Inne rozumienie konfliktu zakłada, iż jest to działanie czy stosunki społeczne typu walki i współzawodnictwa. Trzecie to rozumienie konfliktu jako stanu wrogości między grupami czy osobami ${ }^{1}$.

Przyczyn niezgodności można upatrywać na różnych poziomach życia psychicznego poszczególnych osób, jak również w sytuacjach społecznych. Można przedstawić najważniejsze z nich w następujących kategoriach:

- przyczyny epistemiczne,

- przyczyny aksjologiczne,

- antagonistyczny układ interesów.

Powody epistemiczne odnoszą się przede wszystkim do różnic w wiedzy, kompetencji umysłowych, doświadczenia i położenia, które generuja różnice perspektyw. Powody aksjologiczne odwołują się do wartości tego, co uznajemy za złe, a co za dobre. Różnice te przejawiają się w sprzecznych ocenach i sądach moralnych, sprzecznych reakcjach emocjonalnych i motywach. Antagonistyczny układ interesów odnosi się do sytuacji, w których korzyści jednych ponoszą za sobą konsekwencje

1 B. Szmulik, M. Żmigrodzki, Konflikt polityczny, w: B. Szmulik, M. Żmigrodzki, Wprowadzenie do nauki o państwie i polityce, Lublin 2007, s. 402. 
w postaci straty drugich. Mogą one dotyczyć zarówno potrzeb cielesnych i warunków egzystencji człowieka, jak również potrzeb samopotwierdzenia, szacunku, osobistej kontroli nad rzeczywistością. Jeden i drugi rodzaj potrzeb może się ze sobą łączyć. Sytuacje niezgodności mogą generować konflikty².

Na konflikt polityczny można też spojrzeć jako na przeciwstawne działania dwóch lub więcej podmiotów polityki, wynikające $\mathrm{z}$ ich wzajemnie sprzecznych interesów. Interesy te mogą dotyczyć następujących czterech obszarów: sprawowania władzy i wywierania wpływu w systemie politycznym, partycypacji $\mathrm{w}$ tworzeniu i dystrybucji dóbr materialnych, statusu poszczególnych podmiotów w strukturze społecznej, szans kształtowania, upowszechniania i realizacji systemów wartości związanych ze sferami: cywilizacyjna, ideologiczna, polityczna, etyczną, religijną. Podstawowym przedmiotem sporów jest dostęp do władzy, który może być rozumiany dwojako, po pierwsze jako jej sprawowanie lub współsprawowanie, po drugie, jako możliwość wywierania wpływu i spowodowania decyzji merytorycznych, organizacyjnych i personalnych. Konflikty występują również w sferach (ekonomicznej, kulturowej, socjalnej), które nie są polityczne, ale mogą takimi się stać, jeśli ich wewnątrzsystemowa regulacja nie powoduje ich rozstrzygnięcia. Może też nastąpić taka sytuacja, że konflikty niepolityczne zostają intencjonalnie lub spontanicznie przekształcone w polityczne ${ }^{3}$.

Dla rozważań nad istotą konfliktu istotne są podejmowane w jego obszarze metody walki. Im bardziej destrukcyjne formy walki są stosowane przez przeciwników, tym większy staje się konflikt. Do najłagodniejszych form walki politycznej należy presja psychologiczna, która może przybrać formę perswazji, namowy, żądania, demonstrowania własnej siły aż do groźby. Poza presją psychologiczną kolejną formą walki jest atak słowny (wyzwiska, szyderstwa, oskarżenia, insynuacje, kompromitacja). Jeszcze inną formą walki jest manipulacja, polegająca na przykład na stosowaniu podstępu, wprowadzaniu w błąd, przekazywaniu fałszywych informacji, oszustwie. Kolejne formy walki obejmują

2 J. Reykowski, Rozwiazywanie sprzeczności ideologicznych i sprzeczności interesów w grupach społecznych - teoria i badania, w: Konflikt i porozumienie. Psychologiczne podstawy demokracji deliberatywnej, red. J. Reykowski, Warszawa 2007, s. 36-37.

3 L. Sobkowiak, Konflikt polityczny - analiza pojęcia, w: Studia z teorii polity$k i$, t. I, red. A. W. Jabłoński, L. Sobkowiak, Wrocław 1996, s. 127-128. 
sferę materialną walczących: zastosowanie środków administracyjnych (służbowa degradacja, pozbawienie stanowiska, ograniczenie praw, nałożenie grzywny, kontrybucja, konfiskata, pozbawienie majątku); zastosowanie środków przymusu fizycznego (uwięzienie, wypędzenie, ograniczenie dostępu); atak fizyczny (niszczenie, bicie, torturowanie, zabijanie). Każda forma walki może mieć nasilenie mniej lub bardziej łagodne, co można wyrazić w formie kontinuum ${ }^{4}$.

Cechą charakterystyczną otwartych konfliktów jest występowanie zjawiska dodatniego sprzężenia zwrotnego, które to zjawisko jest przyczyną eskalacji konfliktu. Eskalację można poznać między innymi po pojawieniu się coraz bardziej destrukcyjnych form walki. Innymi wyznacznikami są: poszerzenie obszaru konfliktu, wzrost liczby uczestników konfliktu, który powoduje, iż maleje liczba osób, które są w stanie zachować neutralność. Dochodzi również do wzrostu wagi sprawy, która jest przedmiotem konfliktu. Dla jednostki zaangażowanej w konflikt oznacza to konieczność wydatkowania coraz większej liczby zasobów własnych (czasu, wysiłku, zasobów materialnych) na rzecz walki z przeciwnikiem. Kiedy konflikt przybiera charakter nasilony, uruchamia się „spirala konfliktu” i wymyka się on spod kontroli, wówczas można mówić o konflikcie destrukcyjnym, powodującym straty materialne, duchowe ${ }^{5}$.

Na szeroką skalę miało to miejsce choćby przed wybuchem I wojny światowej. Kiedy ówczesne mocarstwa zgrupowane w dwa potężne bloki militarne trójporozumienia i trójprzymierza doprowadziły do takiej sytuacji, że impulsem do wybuchu wojny stało się bolesne dla Austo-Węgier, ale właściwie błahe z punktu widzenia stabilności państwa zabójstwo arcyksięcia Ferdynanda w Sarajewie. Prawdziwym powodem wybuchu wojny była spirala zbrojeń, a także spirala rosnących oczekiwań społeczeństw europejskich. Państwa trójprzymierza, które z różnych powodów „spóźniły” się do wyścigu o kolonie, pragnęły rozszerzyć swoje panowanie kosztem starych potęg kolonialnych. Rozpoczęły one rozwijanie przemysłu zbrojeniowego i doprowadziły do niespotykanego dotąd rozrostu armii. Zaniepokojone tym państwa/społeczeństwa trójprzymierza, rozkręciły spiralę roszczeń i własnych zbrojeń. Wojna wybuchła, a każdy sądził że udało się sprowokować przeciwnika i że po krótkiej wojnie wrogowie zostaną pokonani.

4 J. Reykowski, Konflikty polityczne, w: Podstawy psychologii politycznej, red. K. Skarżyńska, Poznań 2002, s. 210-211.

5 Ibidem, s. 210, 219. 
Konsekwencje trwania w konflikcie można rozpatrywać na poziomie konsekwencji w poznawczym, jak również emocjonalnym funkcjonowaniu jednostki na gruncie intra- i interpersonalnymi.

Konsekwencje emocjonalne dotyczą przede wszystkim rozbudzenia agresji i wrogości ${ }^{6}$. Jedną z przyczyn wystąpienia agresji jest frustracja, której przyczynek do agresji wyjaśnia hipoteza frustracji - agresji. Frustracja definiowana jest jako stan, który uaktywnia się, gdy aktywność zdeterminowana na cel zostaje zablokowana, a jej intensywność wyznaczana jest przez trzy czynniki: siły motywacji do tej czynności, stopnia jej zakłócenia, liczby zakłóconych poprzednio sekwencji aktywności ukierunkowanej na cel. Siła agresji jest wprost proporcjonalna do siły frustracji? .

W historii zjawisko to można było zaobserwować w Weimarskich Niemczech. Po klęsce w I wojnie światowej, tylko nieliczni zdawali sobie sprawę z tego w jak katastrofalnym położeniu znalazły się Niemcy jesienią 1918 roku. Kontynuacja działań wojennych groziła nie tylko kompletną zapaścią gospodarczą, ale również przeniesieniem działań wojennych na terytorium Rzeszy i ostateczną klęskę. Tak więc dla świadomych sytuacja była jasna trzeba było podjąć rokowania. Jednak rozejm z 11 listopada 1918 r., a później pokojowy Traktat Wersalski z czerwca 1919 roku, były dla większości społeczeństwa niemieckiego niezrozumiałe stąd wzrastająca frustracja i powstanie mitu noża wbitego w plecy niemieckiego żołnierza. Mit ten w zależności od poglądów wygłaszającego, wskazywał jako tego, kto ten nóż wbijał, albo szeroko pojętą klasę polityczną, albo równie szeroko pojmowaną grupę wywrotowców.

Frustrację tę już w latach dwudziestych XX wieku próbował wykorzystać Adolf Hitler, ale pełen sukces osiagną w roku 1933, gdy został kanclerzem Niemiec. Jego dalsze postępowanie skierowało rozbudzoną agresję na niearyjczyków, a w szczególności na Żydów. Co z kolei zaowocowało konfliktem zbrojnym na niewyobrażalną dotąd skalę. Pomimo zwyrodnienia i zbrodni niewielka liczba Niemców przestała wierzyć

6 J. Reykowski, Konflikty polityczne, w: Podstawy psychologii politycznej, red. K. Skarżyńska, Poznań 2002, s. 220.

7 P. G. Zimbardo, F. L. Ruch, Psychologia i życie, Warszawa 1996 s. 586, za: J. Dollard, L. W. Doob, N. Miller, O. H. Mowrer, R. R. Sears, Frustration and aggression, Yale University Press, New Haven 1939. 
Fuererowi, aż do chwili gdy alianckie bomby zaczęły niszczyć Niemieckie miasta.

Wrogość może przerodzić się w niekontrolowane akty zemsty ${ }^{8}$. Sytuację taką możemy zauważyć podczas konfliktu jugosłowiańskiego w latach 90-tych XX wieku. Gdy północne republiki federacji jugosłowiańskiej Słowenia i Chorwacja ogłosiły niepodległość rozpoczęło to okrutną wojnę, która przyniosła nie tylko olbrzymią liczbę poległych, ale i zamordowanych z zimną krwią ofiar, w pewnym momencie często brutalne działania wojskowe przekształciły się w niekontrolowane rzezie narodowościowe, powstrzymane dopiero przez interwencję zbrojną NATO. Państwa, które powstały na gruzach byłej Jugosławii nie potrafią do dziś zabliźnić tej rany.

W obszarze percepcji sytuacji dochodzi do nadmiernego interpretowania wszystkich faktów mogących świadczyć o złych intencjach i niegodnych czynach swoich adwersarzy. Natomiast swoje zachowania interpretować w kategoriach szlachetności i wysokich standardów moralnych. Jeżeli konflikt dotyczy grup może dodatkowo zaistnieć zjawisko polaryzacji przekonań, w wyniku którego przekonania stają się nie tylko bardziej utrwalone, ale i bardziej radykalne. Rozwiązaniu sytuacji konfliktowej nie służy też właściwość percepcji człowieka w sytuacji konfliktu, dochodzi bowiem do zmian w systemie przetwarzania informacji, co powoduje, iż zawęża się zakres dostępnych możliwości, a sytuacja spostrzegana jest w charakterze albo - albo, a jej rozwiązanie możliwe jest tylko przy użyciu siły i/lub podstępu. Następuje zjawisko zaangażowania w konflikt bardzo wielu zasobów ${ }^{9}$. Źródła konfliktów politycznych można upatrywać nie tyle w obiektywnej sytuacji zagrożenia, co w subiektywnej interpretacji ${ }^{10}$.

Sytuację konfliktu można potraktować, w kategoriach zagrożenia zasobów człowieka.

Zasoby w rozumieniu teorii zachowania zasobów Stevana E. Hobfolla rozumiane są w czterech kategoriach:

8 J. Reykowski, Konflikty polityczne, w: Podstawy psychologii politycznej, red. K. Skarżyńska, Poznań 2002, s. 221.

9 J. Reykowski, Konflikty polityczne, w: Podstawy psychologii politycznej, red. K. Skarżyńska, Poznań 2002, s. 221-222; J. Reykowski, Logika walki: szkice z psychologii konfliktu społecznego w Polsce, Warszawa 1984, s. 61-66.

10 J. Reykowski, Konflikty polityczne, w: Podstawy psychologii politycznej, red. K. Skarżyńska, Poznań 2002, s. 224. 
- zasoby materialne, jako przedmioty, mają charakter fizyczny, lub przedstawiają dodatkową wartość związaną z rzadkością i kosztem nabycia, są cenione ze statusem, albo samoocena, mogą mieć znaczenie do przetrwania;

- zasoby stanu, cenione i poszukiwane okoliczności, dla przykładu można wymienić: małżeństwo, posada, starszeństwo, zdrowie, dotyczą przede wszystkim pełnionych przez człowieka ról społecznych, są szczególnie cenne, ponieważ to dzięki nim często mamy dostęp do innych cennych wartości;

- zasoby osobiste, cechy osobowości, które sprzyjają odporności na stres, umiejętności, kompetencje zawodowe, umiejętności społeczne, zdolności przywódcze, samoocena, optymizm, poczucie własnej skuteczności, nadzieja;

- zasoby energii, do której zaliczane są czas, pieniądze, wiedza, wiarygodność kredytowa, które są istotne do zdobywania innych zasobów, można je bowiem na nie wymieniać.

Wszystkie wymienione wyżej kategorie zasobów można odnaleźć w polityce. Podstawowym zasobem stanu w polityce jest posiadanie władzy, możliwość wywierania wpływu, prestiż, przywileje polityczne, stanowiska w strukturach władzy, mogą one bowiem stanowić źródło dalszych spodziewanych korzyści. Zasoby materialne stanowić może terytorium i występujące na nim cenne dla ludzi potencjały. Zasoby osobiste cenione w polityce to dla przykładu poczucie skuteczności, wizerunek publiczny, umiejętności przywódcze, kompetencje zawodowe i komunikacyjne, systemy wartości; zasoby energii są na tyle uniwersalne, że można je odnieść do każdej sfery.

Co interesujące, Hobfoll w pierwszych pracach nie wyróżnia wsparcia społecznego, traktuje je bowiem, jako zasób tylko o tyle o ile przyczynia się on do zabezpieczenia innych cenionych przez człowieka zasobów, później jednak wpisuje je w kategorie zasobu stanu czy energii $^{11}$. Bez wątpienia w świecie kontaktów politycznych zasoby związane ze wsparciem społecznym mają szczególne znaczenie, choćby z punktu widzenia funkcjonowania w pewnej sferze lojalności i dyscypliny partyjnej, przede wszystkim zaś wsparcie społeczne dla polityka stanowią wyborcy.

11 S. E. Hobfoll, Zachowanie zasobów. Nowa próba konceptualizacji stresu, „Nowiny Psychologiczne” 1989, nr 5-6, s. 35-37; S. E. Hobfoll, Stres, kultura i społeczność. Psychologia i filozofia stresu, Gdańsk 2006, s. 74-76. 
Stres psychologiczny związany jest z sytuacjami groźby utraty zasobów, rzeczywistej ich utraty lub brakiem sił spowodowanych ich wyczerpaniem. Strata nie musi być realna, wystarczy samo jej spostrzeżenie lub groźba. Aby rekompensować straty człowiek angażuje te zasoby, które pozostały do przekształcenia ich w inne, spostrzegane jako cenniejsze. Przykładowo poświęcają czas i energię dla uzyskania pieniędzy lub wła$\mathrm{dzy}^{12}$. Teza odnośnie tendencji człowieka do zachowania zasobów została przez Hobfolla uzupełniona stwierdzeniem, że człowiek dodatkowo dąży do promowania tego, co ceni, więc stres psychologiczny pojawi się również w sytuacji braku wzrostu zasobów po ich zainwestowaniu ${ }^{13}$.

Istotna jest ocena zasobów, można ją rozpatrywać w kategoriach oceny pierwotnej i wtórnej. Pierwotna odnosi się do oceny, czy dane wydarzenie, stanowi zagrożenie dla jednostki. Można wyróżnić trzy rodzaje znaczenia zdarzeń: stresujące, bez znaczenia oraz sprzyjająco-pozytywny. Natomiast ocena wtórna dotyczy oceny przez jednostkę posiadanych przez siebie zasobów, czy są one wystarczające do poradzenia sobie z zaistniałą sytuacją ${ }^{14}$. Człowiek może bronić się przed utratą zasobów poprzez ponowną interpretację zdarzenia ocenionego, jako zagrażające w kategoriach wyzwania. Możliwe i skuteczne jest też przewartościowanie utraconych zasobów. Natomiast dla ochrony przed przyszłymi stratami, człowiek gromadzi zasoby, inwestuje w aktualne w celu zwiększenia zysku w przyszłości ${ }^{15}$.

W sytuacji konfliktu politycznego istnieje realna szansa zagrożenia zasobów lub ich realnej straty, pojawienie się więc stresu jest jego naturalną konsekwencją. Z drugiej strony konflikty polityczne mogą pojawić się również w sytuacji, gdy jedna ze stron promuje swoje zasoby. Oczywiście najważniejsza jest interpretacja tego co dzieje się w obszarze konfliktowym. Gromadzenie zasobów w polityce polega przykładowo na zdobywaniu jak największej liczby wyborców, zajmowanie jak największej liczby stanowisk i posiadania wpływów w instytucjach władzy. Inwestowanie można utożsamiać z prowadzeniem kampanii politycznej.

12 S. E. Hobfoll, Stres, kultura i społeczność. Psychologia i filozofia stresu, Gdańsk 2006, s. 34-35.

13 Ibidem, s. 71-72.

14 R. S. Lazarus, S. Folkman, Stress, appraisal and coping, New York 1984, s. $31-35$.

15 S. E. Hobfoll, Zachowanie zasobów. Nowa próba konceptualizacji stresu, „Nowiny Psychologiczne” 1989, nr 5-6, s. 42-44. 
Ważne w teorii zachowania zasobów jest pojęcie straty, bowiem to utrata zasobów jest niewspółmiernie bardziej wyrazista od zysku. Silniejszy na człowieka wpływ wywiera strata i motywacja do jej uniknięcia niż zysk i motywacja do jego osiąnnięcia ${ }^{16}$. Dlatego też ludzie muszą inwestować zasoby, by zapobiegać ich utracie, rekompensować sobie straty oraz zyskiwać nowe zasoby. Jednym z mechanizmów inwestowania zasobów jest bezpośrednie ich wydatkowanie, dla przykładu inwestowanie czasu lub pieniędzy celem ochrony innych zasobów. Inną metodą jest podejmowanie ryzyka bez bezpośredniego inwestowania, na przykład poddawanie w zastaw jednego zasobu w celu wzrostu innych. Możliwa jest też taka sytuacja, że inwestowanie zasobów zachodzi wprost ${ }^{17}$.

Reguły rządzące zasobami, ich działaniem na przestrzeni czasu Hobfoll ujął w czterech zasadach:

- osoby, które dysponują większymi zasobami są mniej narażone na ich utratę i mają większe możliwości osiagania zysku, natomiast osoby o niskim poziomie zasobów są bardziej narażone na straty, po doświadczeniu początkowej straty rzadko są w stanie dokonywać koniecznych inwestycji zasobów;

- niedostatek zasobów nie tylko powoduje wzrost ryzyka straty, ale powoduje też, że początkowa strata pociaga za sobą następne, jednostki bowiem muszą wykorzystywać posiadane zasoby do radzenia sobie ze stratą, a w miarę uszczuplania puli zasobów zmniejsza się prawdopodobieństwo poradzenia sobie z przyszłymi wyzwaniami, a uruchomiona zostaje spirala strat, która nabiera dodatkowo rozpędu;

- ludzie posiadający zasoby są bardziej zdolni do osiagania zysków, a zysk początkowy pociaga za sobą dalsze zyski;

- osoby, którym brakuje zasobów są skłonne przyjmować postawę defensywną i strzec tego, co maja, bowiem postawa defensywna umożliwia zachowanie w rezerwie maksymalnej ilości zasobów, na wypadek gdyby w przyszłości była konieczność przeciwdziałania skutkom ciągu poważnych strat ${ }^{18}$.

Zasady te mają odniesienie do sytuacji konfliktów politycznych.

Istnieją zasoby, których liczba jest ograniczona, jeśli są one szczególnie pożądane i nie wystarczy ich dla wszystkich chętnych, dochodzi

16 S. E. Hobfoll, Stres, kultura i społeczność. Psychologia i filozofia stresu, Gdańsk 2006, s. 78 .

17 Ibidem, s. 90-91.

18 Ibidem, s. 97-100. 
do konfliktu o zasoby. Rywalizacja o zasoby generuje stres. Hobfoll wskazuje, iż konflikt może przybierać różne formy. Szczególny rodzaj konfliktu następuje wtedy, gdy dotyczy on konfliktu międzygrupowego. Zachodzą wtedy specyficzne mechanizmy w obrębie grupy. Konflikty wewnętrzne ulegają osłabieniu, większość zasobów zostaje przesuniętych na rzecz działań rywalizacyjnych. Na rzecz walki o zasoby zostają zaangażowane więzi społeczne, ludzie organizują się w celu uzyskania, utrzymywania, ochrony i promowania zasobów. Organizowanie się celem zdobywania zasobów może mieć charakter formalny, na przykład rządu. Istota wpływu konfliktu na zasoby jednostki jest taka, iż rywalizacja wiąże zasoby indywidulane w zasoby grupowe, na przykład poczucie własnej wartości, nadzieja czy kompetencje zawodowe, a co za tym idzie wypracowane przez ludzi indywidualne skrypty są wytworem uniwersalnych konfliktów ról społecznych ${ }^{19}$.

Jednomyślność i brak konfliktu też nie jest dobra, prowadzi do stagnacji, a przede wszystkim do podejmowania decyzji błędnych. Pisał o tym Irving Janis, wskazując na główne symptomy występowania syndromu myślenia grupowego: iluzja wszechmocy i nieomylności grupy, unikanie przez grupę informacji o ostrzeżeniach, wątpliwościach, wiara we wrodzoną wyższość moralną członków grupy, postrzeganie przywódców wroga, jako zbyt złych, aby wchodzić z nimi w układy, nacisk na członków grupy, którzy wyrażają poglądy sprzeczne z stereotypami grupy, iluzja jednomyślności, tendencja do poszukiwania zgody, tendencja do komunikowania się tylko na tematy, co do których istnieje zgodność w obrębie grupy, stworzenie ról grupowych, których przedstawiciele mają za zadanie stać na straży jednomyślności ${ }^{20}$. Można zinterpretować syndrom myślenia grupowego w kategorii ochrony zasobów takich jak: poczucie bycia członkiem grupy, utrzymania dobrego mniemania na własny temat, zachowania poczucia posiadania racji, poczucia pewności siebie członków grupy, być może również własnych interesów, likwidacja lęku i niepewności. Spostrzeganie konfliktu jako zagrożenia lub straty może przynieść takie konsekwencje. Możliwe jest natomiast przyjęcie interpretacji, iż konflikt to wyzwanie do stworzenia nowej jakości. Wyzwanie jest dla człowieka transakcją, która pojawia się, gdy oceniamy wydarzenia jako trudne, lecz możliwe do spełnienia i gdy jednostka jest

19 Ibidem, s. 77-78.

20 I. L. Janis, Victims of Groupthink. A psychological study of foreign - policy decisions and fiascoes, Boston 1972, s. 197-198. 
przekonana o możliwości poradzenia sobie za pomocą posiadanych lub możliwych do zdobycia umiejętności ${ }^{21}$.

Zjawisko funkcjonowania zasobów w konflikcie można rozpatrywać z perspektywy funkcji konfliktu.

Stanisław Chełpa i Tomasz Witkowski proponują model wyjaśniający relacje pomiędzy aktywnością w konflikcie a efektywnością i jakością wzajemnych interakcji stron. Przez efektywność rozumiana jest zdolność do wypracowywania porozumień, jakość wyznacza zadowolenie stron z rozwiązania konfliktu. Przy niskiej aktywności w konflikt możliwe jest niepowodzenie spowodowane stagnacja, przy wysokim natomiast niepowodzenie wywołane chaosem, spór mógłby się rozszerzyć angażując innych ludzi, inne interesy. Najbardziej pożądany jest optymalny poziom konfliktu, jego skutkiem jest najwyższa efektywność i jakość wzajemnych interakcji ${ }^{22}$.

$\mathrm{Na}$ fakt integracji wewnątrz struktur grupy zaangażowanej w konflikt zwraca też uwagę Leszek Sobkowiak. A utrzymanie i trwałość tej tendencji zależy przede wszystkim od wyniku konfliktu: zwycięstwo generuje wzrost integracji, porażka jej rozpad. Tendencje integracyjne i dezintegracyjne mogą występować we wszystkich strukturach systemu zaangażowanego w spór: w centralnym ośrodku decyzyjnym, ośrodkach lokalnych, różnorakich grupach interesu i w relacjach poszczególnych członków. Reakcje osób zaangażowanych w konflikt mogą być niejednolite $^{23}$

Zarówno negatywne, jak i pozytywne konsekwencje konfliktu podkreśla Zofia Rummel-Syska. Spośród negatywnych wymienia i podkreśla:

- stratę energii, która mogłaby zostać wykorzystana do realizacji zadań,

- obniżenie morale,

- dezintegrację jednostek i grup,

- pogłębienie różnic między ludźmi,

- niszczenie współpracy,

- ujawnienie nieracjonalnych zachowań,

- podejrzliwość i brak zaufania,

- obniżenie wydajności i jakości pracy.

21 R. Lazarus, Paradygmat stresu i radzenia sobie, „Nowiny Psychologiczne” 1986, nr 3-4, s. 19 (2-39).

22 S. Chełpa, T. Witkowski, Psychologia konfliktów, Wrocław 2004, s. 146-147.

23 L. Sobkowiak., Konflikt polityczny - analiza pojęcia, w: Studia z teorii polity$k i$, t. I, red. A. W. Jabłoński, L. Sobkowiak, Wrocław 1996, s. 124. 
Natomiast pozytywne konsekwencje to:

- otwarta konfrontacja,

- wyjaśnienie wielu spraw,

- usprawnienie procesów rozwiązywania problemów,

- podniesienie poziomu zaangażowania stron,

- przepływ informacji między stronami,

- inicjowanie procesu doskonalenia się i rozwoju stron,

- umocnienie kontaktów między stronami, pod warunkiem, iż konflikt zostanie rozwiązany konstruktywnie,

- wzrost efektywności działania,

- wzmocnienie poczucia tożsamości stron ${ }^{24}$.

Konflikt polityczny z perspektywy teorii zachowania zasobów można rozpatrywać w kategorii jego funkcji dwojako. Po pierwsze, konflikt konstruktywny może stanowić mechanizm wzrostu zasobów, stanowi jego swoistą inwestycję, pomaga w rozwoju stron, wzmacnia efektywność działania, można nawet zaryzykować stwierdzenie, iż stanowi pewną inwestycję. W dużej mierze ocena zależy to od rezultatu sporu, od poczucia, iż bilans zysków i strat jest dodatni, iż nastapił wzrost zasobów po ich zainwestowaniu. Konflikt może też stanowić siłę destrukcyjną wobec posiadanych przez strony zasobów. Zawsze będzie on powodował umniejszenie pewnych zasobów (choćby czasu czy energii), może jednakże spowodować bezzwrotne straty jednych cennych wartości, bez wzrostu innych. Istotna dla rezultatu sporu i ostatecznej jego oceny może być metoda, za pomocą której konflikt został rozwiązany, pewne metody wydają się być szczególnie użyteczne dla zachowania zasobów. Przede wszystkim negocjacje oparte na zasadach: oddzielaj ludzi od problemu, skoncentruj się na interesach, a nie na stanowiskach, staraj się znaleźć możliwości korzystne dla obu stron, nalegaj na stosowanie korzystnych kryteriów. Oczywiście nie zawsze możliwe jest rozwiązywanie sporów za pomocą negocjacji i dla wielu konfliktów politycznych ta metoda jest zupełnie nieadekwatna. Człowiek przystępuje do konfliktu, inicjuje go lub daje się do niego zaprosić, gdy ma nadzieję na uzyskanie korzyści lub musi bronić posiadane zasoby. Konflikt sam w sobie może być zasobem ze względu na korzyści występujące w związku z jego powstaniem, utrzymaniem. Zyskiem może być choćby wzmoc-

24 Z. Rummel-Syska, Konflikty organizacyjne. Ujęcie makrospołeczne, Warszawa 1990 , s. $21-22$. 
nienie struktur wewnątrzgrupowych, systemowych czy ugruntowanie poparcia wśród wyborców, uzyskanie zainteresowania, wymuszenie opowiedzenia się po którejś ze stron. Eryk Mistewicz w rozmowie z Michałem Karnowskim odnosi się do rywalizacji w ten sposób: „...Antagonista nadaje sens walce naszego bohatera. Sprawia, że kibicujemy mu z całych sił. Pomyśl przez chwilę, co by było z Coca-Colą, gdyby nie wymyśliła sobie swojego największego rywala?

[...]...gdyby nie Platforma Obywatelska, której szalenie jest potrzebny taki PiS, jaki jest, nie byłoby być może PiS-u. A przynajmniej w tej skali. Tak jak PiS jest potrzebny Platformie, tak Pepsi jest potrzebna Coca-Coli. Mechanizm jest podobny. Roberto Goizueta, były szef Coca-Coli w latach 90., bardzo świadomie zastosował tę technikę. Później zdradził w «Fortunie», że jeśli jakaś firma nie ma swojego naturalnego przeciwnika, musi go sobie znaleźć. Jeśli ma niewielkiego przeciwnika - powinna go hołubić, budować, cieszyć się, że rośnie. Tylko tak doprowadzi bowiem do wojny. [...] Ta wojna, «wojna o colę», zdominowała ogląd rynku, wyzwoliła potężną energię marketingową i reklamową, użytą przez obydwie walczące strony. Wtedy, w szaleńczej gonitwie za nowymi technikami promocji w miejscach sprzedaży, odkryto nowe segmenty rynku i wręcz nowe rynki. Zarobiono naprawdę wielkie pieniądze" 25 . Istotne przy podejmowaniu decyzji o zaangażowaniu się w konflikt może być świadomość czemu konflikt naprawdę służy.

\section{Bibliografia}

Chełpa S., Witkowski T., Psychologia konfliktów, Wrocław 2004.

Hobfoll S. E., Zachowanie zasobów. Nowa próba konceptualizacji stresu, „Nowiny Psychologiczne" 1989, nr 5-6, s. 24-48.

Hobfoll S. E., Stres, kultura i spoleczność. Psychologia i filozofia stresu, Gdańsk 2006.

Janis I. L., Victims of Groupthink. A psychological study of foreign - policy decisions and fiascoes, Boston 1972.

Karnowski M., Mistewicz E., Anatomia władzy, Warszawa 2010.

Lazarus R. S., Folkman S., Stress, appraisal and coping, New York 1984.

Lazarus R. S., Paradygmat stresu i radzenia sobie, „Nowiny Psychologiczne” 1986, nr 3-4, s. 2-39.

${ }^{25}$ M. Karnowski, E. Mistewicz, Anatomia władzy, Warszawa 2010, s. 44-45. 
Reykowski J., Logika walki: szkice z psychologii konfliktu społecznego w Polsce, Warszawa 1984.

Reykowski J., Konflikty polityczne, w: Podstawy psychologii politycznej, red. K. Skarżyńska, Poznań 2002, s. 208-236.

Reykowski J., Rozwiqzywanie sprzeczności ideologicznych i sprzeczności interesów $w$ grupach spolecznych - teoria i badania, w: Konflikt i porozumienie. Psychologiczne podstawy demokracji deliberatywnej, red. J. Reykowski, Warszawa 2007.

Rummel-Syska Z., Konflikty organizacyjne. Ujęcie makrospołeczne, Warszawa 1990.

Sobkowiak L., Konflikt polityczny - analiza pojęcia, w: Studia z teorii polityki, t. I, red. A. W. Jabłoński, L. Sobkowiak, Wrocław 1996, s 117-131.

Szmulik B., Żmigrodzki M., Konflikt polityczny, w: B. Szmulik, M. Żmigrodzki, Wprowadzenie do nauki o państwie i polityce, Lublin 2007.

Zimbardo P. G., Ruch F. L., Psychologia i życie, Warszawa 1996, za: J. Dollard, L. W. Doob, N. Miller, O. H. Mowrer, R. R. Sears, Frustration and aggression, New Haven 1939.

\section{Political conflict from the point of view of the conservation of resources}

\section{Summary}

This paper analyzes the phenomenon of political conflict from the point of view of Stevan. E. Hobfoll's Conservation of Resources theory. The first part is devoted to considerations on the principal sources of political conflict and the general pattern of its course in view of selected theories from political science and psychology. It presents the mechanisms of both cognitive and emotional functioning of individuals and groups in a conflict situation. The second part reviews the basic assumptions of the Conservation of Resources theory. This encompasses considerations on the resources that are politically significant, their definitions, and conclusions on the management of political resources. First and foremost, the analysis concerns the functions of conflict which may constitute a source of both an increase in, and loss of resources; additionally, conflict as such can also be perceived and treated as a kind of resource. The paper presents examples of political events in the $19^{\text {th }}$ and $20^{\text {th }}$ centuries. 
